\title{
PENGEMBANGAN PERANGKAT PEMBELAJARAN E-LEARNING MATA KULIAH WAWASAN PENDIDIKAN DASAR, TELAAH KURIKULUM PENDIDIKAN DASAR, PENDIDIKIAN IPS SEKOLAH DASAR, PERSPEKTIF GLOBAL DAN PROBLEMATIKA PENDIDIKAN DASAR
}

\author{
Wayan Lasmawan \\ Program Pascasarjana, Universitas Pendidikan Ganesha \\ Singaraja, Indonesia
}

email: lasmawanizer@yahoo.com

\begin{abstract}
Abstrak
Penelitian ini bertujuan untuk mengembangkan model pengorganisasian materi dan perangkat penilaian pembelajaran mata kuliah wawasan pendidikan dasar, pendidikan, filsafat IImu, dan perspektif global yang berbasis sosial budaya secara integratif dan holistik yang mencakup domain kognisi, afeksi, nilai, dan psikomotor. Penentuan sampel untuk validasi digunakan dua tahap yaitu expert sampling pada dua orang ahli dalam bidang itu, dan sampling purposive yang digunakan sebagai sampling penelitian. Penelitian ini merupakan penelitian payung, sehingga dalam proses pelaksanaannya akan memayungi penelitian tesis 12 orang mahasiswa Program Pascasarjana Undiksha, yang masih aktif, yaitu mereka yang saat ini berada di semester I dan semester III, khususnya mahasiswa Program Studi Pendidikan Dasar (S2 Pendas). Metode pengumpulan data menggunakan kuesioner yang dikombinasikan dengan rubrik. Setelah data terkumpul, data dianalisis menggunakan analisis deskriptif kuantitatif dan kualitatif. Hasil Penelitian menunjukkan bahwa kesesuaian dan kedalaman materi, pengorganisasian materi, penggunaan bahasa, dan kepraktisan konten E-learning, terkategori sangat baik. Berdasarkan analisis kualitatif didapatkan simpulan bahwa perlu ditambahkan pendekatan penelitian kombinatif (Mix Method) sebagai suatu sub-bahasan.
\end{abstract}

Kata kunci: Perangkat Pembelajaran E-Learning, Wawasan Pendidikan Dasar, Telaah Kurikulum Pendidikian IPS, Perspektif Global, Problematika.

\begin{abstract}
This research aims to develop a model of organizing learning materials and assessment tools insight basic education courses, education, philosophy of science, and global perspective is based on socio-cultural and holistic integrative domain includes cognitive, affective, value, and psychomotor. The samples used for validation of two stages: expert sampling at two experts in the field and purposive sampling were used as a sampling study. This research is an umbrella, so that the implementation process will be an overarching thesis research 12 Undiksha Graduate students, who are still active, is they are currently in the first semester and third semester, especially students of the post graduate program. Methods of data collection using a questionnaire combined with a rubric. Once the data is collected, the data were analyzed using descriptive analysis of quantitative
\end{abstract}


and qualitativec. Results showed that the suitability and depth of the material, organizing materials, use of language, and the practicality of e- learning content, categorized very well. Based on qualitative analysis obtained conclusion that needs to be added kombinatif research approach (Method Mix) as a subdiscussion.

Keywords : E - Learning Tools Learning, Insights Basic Education, Assessing Basic Education Curriculum, Pendidikian IPS Elementary School, Global Perspectives, Problems of Basic Education.

\section{PENDAHULUAN}

Pendidikan yang ideal hakikatnya selalu bersifat antisipatif dan prepatoristik, yakni selalu mengacu ke masa depan, dan selalu mempersiapkan generasi muda untuk kehidupan masa depan yang jauh lebih baik, bermutu, dan bermakna. Sungguhpun demikian, apa dan bagaimana pendidikan ideal dengan sifatnya yang antisipatif dan prepatoristik seperti itu, berbeda bagi setiap bangsa dalam melihat dan menghadapi masa depannya. Bagi bangsa Indonesia, kondisi, tantangan, dan masalah masa depan yang harus dihadapi senantiasa berkaitan dengan pengembangan kualitas dan kemandirian manusia Indonesia yang memungkinkannya mampu dan proaktif menjawab tantangan globalisasi, baik di bidang sosial, budaya, ekonomi, politik, ilmu pengetahuan, dan teknologi.

Pendidikan yang ideal bagi bangsa Indonesia, menurut UndangUndang Nomor 20 Tahun 2003 tentang Sistem Pendidikan Nasional adalah pendidikan yang mampu mengembangkan kemampuan dan membentuk watak serta peradaban bangsa yang bermartabat dalam rangka mencerdaskan kehidupan bangsa (psl. 3): serta secara aktif mengembangkan kapasitas siswa untuk memiliki kekuatan spiritual, keagamaan, pengendalian diri, kepribadian, kecerdasan, akhlak mulia, serta keterampilan yang diperlukan dirinya, masyarakat, bangsa, dan negara (psl. 1:1) (Depdiknas, 2004). Berpijak pada pemikiran tersebut, maka setiap komponen dalam sistem pendidikan nasional secara sinergis dan integratif harus mengacu dan mendukung tercapainya kondisi pendidikan ideal dimaksud. Sayangnya, dari hasil refleksi kritis dan mendalam atas pemikiran dan praktik pendidikan yang terjadi di Indonesia hingga dewasa ini, Buchori (2001) menengarai bahwa sifat sistem pendidikan ideal yang antisipatif dan prepatoristik seperti itu telah kehilangan momentum untuk mengikhtiarkan pembentukan dan pengembangan kesadaran akan harkat dan martabat bangsa.

Buchori (2001) mencatat bahwa fenomena tersebut terjadi semenjak tahun 1960-an, di mana sejak itu sistem pendidikan Indonesia telah kehilangan watak kultural yang patut dibanggakan. Padahal, sebelum itu pendidikan Indonesia telah mampu membentuk dan menghasilkan tokoh yang patut diteladani. Sejalan dengan pandangan tersebut, program pendidikan di Indonesia tak lebih dari kepanjangan tangan birokrasi dalam upaya menanamkan kepentingannya melalui media instruksional, dimana sistem pendidikan yang kemudian 
terejawantahkan dalam kurikulum pendidikan nasional tak ubahnya seperti mesin, sedangkan remote control-nya sepenuhnya berada di birokrasi. Institusi sekolah sama sekali tak memiliki ruang dan daya untuk mengembangkan diri, hanya mengabdi semata-mata pada keputusan dari atas yang lebih sering tidak relevan pemikiran dasar maupun pelaksanaannya (Buchori, 2001). Mengenai penomena salah kaprah dunia pendidikan di Indonesia tersebut, Hasan (2006) menyatakan bahwa praktek pendidikan telah mengabaikan akomodasi budaya dalam standar kompetensi lulusan (SKL) maupun standar isi (SI), sehingga produk pendidikan gersang dari pembekalan nilai-nilai sosial dan budaya bangsa. Tingkat prestasi, keberhasilan, dan kesuksesan siswa dalam praktek pembelajaran di sekolah, semata diukur dari perolehan nilai yang didapat siswa bersangkutan, dengan mengabaikan evaluasi terhadap kompetensi nilai-nilai budaya bangsa yang dipahami oleh siswa. Akibatnya jelas, evaluasi program dan sikap serta perilaku siswa memiliki ruang masing-masing.

Hasil analisis dan refleksi Raharjo (2004) juga mengungkapkan bahwa pendidikan nasional gagal atau belum berhasil menghasilkan kaderkader bangsa yang berkemauan tulus dan berkemampuan profesional. Akibatnya, kehidupan bangsa Indonesia dewasa ini, khususnya di bidang sosial dan budaya dicirikan oleh semakin hilang dan menjauhnya jati diri bangsa dari perilaku masyarakat, utamanya para elit, dalam kehidupan berbangsa dan bernegara. Selain itu juga tejadi pembentukan sikap, watak, dan kepribadian siswa, ternyata pendidikan belum menunjukkan hasil seperti yang diharapkan oleh masyarakat. $\mathrm{Hal}$ ini dapat diamati dari kecenderungan terjadinya kenakalan remaja, kemerosotan moral, dan perilaku menyimpang dari etika kehidupan dan budaya bangsa. Sekolah yang diharapkan menjadi salah satu wahana terjadinya proses transformasi nilai-nilai budaya dan norma-norma sosial sebagai bagian dari pembentukan kepribadian siswa belum menjadi kenyataan (Dantes, 2008). Padahal sekolah semestinya mampu menjadi agen perubahan dalam membentuk manusia Indonesia seutuhnya yaitu manusia yang tidak hanya pandai secara akademik, yang mempunyai keahlian, keterampilan, dan kemampuan intelektual dalam memecahkan masalah, tetapi juga mempunyai integritas moral dan ketahanan budaya yang mapan. Salah satu program persekolahan yang memikul beban dalam kaitannya dengan pembentukan dan pembekalan pengetahuan, keterampilan, nilai, dan moral siswa sebagai warga negara potensial adalah mata pelajaran.

Pembelajaran yang secara formal mulai diberlakukan dari jenjang sekolah dasar sampai SMA, dituntut untuk mampu memediasi pengembangan dan pelatihan potensi siswa secara optimal, khususnya yang bertalian dengan transformasi nilai-nilai budaya dan norma sosial (Sumantri, 2004). Masih dengan makna yang sama NCSS (2008) menyatakan bahwa: social studies aims to educate students to become caring, well informed citizens: realizing and connecting the social studies to one's sense of freedom and everyday lifestyle: examining the code of 
behavior within one's diverse society. Melalui pembelajaran yang pengertiannya disepadankan dengan social studies, siswa akan belajar memahami dan memahiri nilai-nilai dasar yang diperlukan untuk hidup secara mapan di masyarakat, yaitu nilai mengenai: awareness of stereotypes, bias, and point of view, awareness of multiple cultures, tolerance of cultural differences, and protecting individual right to difference (Saidiman, 2008: NCSS, 2008). Namun realitas yang ada di lapangan, ternyata masih jauh dari harapan sebagaimana ditegaskan dalam UUSPN Nomor 20 Tahun 2003.

Bersandar pada kondisi di atas, patut dipertanyakan peranan dan esensi dari pembelajaran sebagai salah satu program pendidikan yang diperuntukkan untuk membangun dan membentuk karakter kebangsaan siswa secara dini. Penegasan terhadap preposisi ini, telaah Hasan (2006), cukup menggambarkan ketidakberpungsian pembelajaran dalam membangun karakter ke-indonesiaan, yaitu: pembelajaran saat ini sangat miskin dengan pembekalan pendidikan moral, nilai, dan keterampilan sosial, sehingga kurang menantang siswa untuk belajar, apalagi memahami karakteristik bangsanya. Kondisi geografis dan keberagaman etnis, budaya, bahasa, dan agama yang menjadi ciri khas bangsa indonesia, hendaknya mampu ditanamkan dan dibiasakan kepada siswa melalu pembelajaran (Sumantri, 2004). Karena melalui pembelajaran, siswa dapat belajar memahami, memahiri, dan membiasakan diri untuk hidup dalam keberagaman nilai-nilai budaya bangsa. Mengenai peranan dan fungsi dari pembelajaran, NCSS (2008), menyatakan bahwa social studies is a term used to describe the broad study of the various fields which involve past and current human behavior and interactions. Also, the study of social groups and group dynamics. Selanjutnya dikatakan pula bahwa melalui social studies, siswa dapat memahami tetang: good citizenship, critical thinking, culture, beliefs, problem solving, cosmopolitanism, and conservation. Berdasarkan kajian empiris dan konseptual di atas, tampak bahwa betapa urgen dan strategisnya pembelajaran dalam kaitannya dengan pembangunan karakter dan paham keindonesiaan bagi siswa. Sebagai sebuah program pendidikan formal yang bersifat synthetik dan holistik, pembelajaran dituntut untuk mampu memperkuat simpul-simpul budaya bangsa, sehingga bangunan masyarakat Indonesia menjadi semakin kokoh (Supriyoko, 2001).

Sebagai program pendidikan pada level persekolahan, mata pelajaran merupakan wahana pendidikan yang mestinya memediasi secara penuh upaya pembangunan daya rekat dan daya tangkal implikasi diversity bagi bangsa-bangsa seperti Indonesia (NCSS, 2008). juga menjadi bahan pendidikan politis untuk keabsahan dan memperkokoh legitimasi pemerintah di mata masyarakatnya. Secara tradisional tujuan pembelajaran selalu dikaitkan atas pandangan transmission and internalization of culture (Hasan, 2006: Lasmawan, 2008). Pandangan tersebut sebenarnya menghendaki pembelajaran sebagai disiplin yang synthetic-holistic dapat menjadi wahana pendidikan untuk mencapai the glorious past dalam arti agar generasi muda dapat menghargai 
masyarakat, budaya bangsa, dan pemerintahnya, terutama untuk memupuk rasa bangga (dignity) sebagai sebuah komunitas yang beradab.

Menurut Mc Michael (2006) dan Lancester (2005), terdapat sejumlah aspek yang menjadi korelat kurang efektifnya pembelajaran, khususnya pada jenjang sekolah dasar (SD) dalam mendukung tercapainya tujuan ideal pendidikan, yang dapat dirangkum dari berbagai hasil penelitian dan analisisreflektif pakar pembelajaran. NCSS (2008) merekomendasikan bahwa: The social studies teacher must approach such issues in...attitudes, ability to study relevant social problems of the past or present and make...teachers to serve as thoughtful curricular-instructional decision makers. Sementara Hasan (2006: 2007) misalnya memandang bahwa model pengorganisasian materi pada jenjang sekolah dasar kurang memuat masalah sosial, budaya, dan nilai dalam hidup keseharian anak, dan lebih berorientasi pada penguasaan struktur keilmuan (sumber keilmuan) daripada realitas sosial budaya keseharian sebagai sumber nilai rujukan bagi anak, terlalu sarat beban muatan, kurang sesuai dengan motivasi dan orientasi belajar anak. Pembelajaran di sekolah dasar juga belum sepenuhnya dipandang mampu mengembangkan kemampuan berpikir tingkat tinggi dan membentukan karakter atau kepribadian umum, sebagai dua hal yang sudah seharusnya menjadi kepedulian dalam pengembangan pembelajaran pada masa mendatang.

Pembelajaran tidak saja menjadi wahana memahami keagungan masyarakat dan budaya oleh siswa, serta media pengembangan kemampuan intelektual ataupun center for excellence, tetapi juga menjadi wahana dalam upaya memperbaiki kehidupan sosial, budaya, politik, dan ekonomi sebuah masyarakat (Lancester, 2005). Artinya, materi yang semestinya disajikan dalam membelajarkan senantiasa bertautan dan mengakomodasi nilai-nilai budaya dan norma sosial aktual yang ada di lingkungan hidup siswa (Sumantri, 2004). Sementara Lasmawan (2008), merekomendasikan bahwa: materi pembelajaran, khususnya pada jenjang sekolah dasar hendaknya senantiasa berangkat dari kebutuhan riil siswa dan akomodasi phenomena sosial-budaya dimana siswa itu tumbuh dan berkembang. Kebutuhan ini semakin mendesak untuk dilakukan, mengingat pembelajaran juga memiliki nilai praktis dan pragmatis bagi siswa untuk memperbaiki pilar-pilar sosial dan budaya masyarakatnya. Kondisi ini sejalan dengan apa yang dikedepankan oleh Lancester (2005), bahwa pembelajaran social studies yang baik adalah bilamana guru mampu menghadirkan potret riil masyarakat dengan berbagai dinamika sosial dan budayanya ke dalam kelas, sehingga siswa tidak merasa asing dengan materi.

Lasmawan (2008) dan NCSS (2007), mengidentifikasi implikasi dari pergeseran paradigma model pengorganisasian materi dari perenialisme ke model rekonstruktivisme, pada dasarnya dimaksudkan untuk lebih merekatkan materi dengan isu-isu aktual dan nilainilai budaya dasar masyarakat dimana pembelajaran itu dikembangkan, serta meningkatkan pemahaman dan 
kesadaran sosial-budaya siswa sebagai warga negera. Implikasi pergeseran paradigma pembelajaran tersebut sangat relevan jika dikaitkan dengan betapa perlunya dasar-dasar budaya dan realitas sosial melandasi setiap aktivitas instruksional pembelajaran yang dikembangkan oleh guru. Pembelajaran berbasis sosial budaya dipandang dari kepentingan integrasi bangsa merupakan suatu keharusan untuk dikembangkan, mengingat kondisi obyektif bangsa Indonesia baik secara historis, antropologis, bahkan teologis adalah plural bahkan mungkin yang paling plural di dunia (Supriyoko, 2001: Dantes, 2008: Lasmawan, 2008).

Pendidikan sebagai salah satu komponen programatik di dalam kurikulum sekolah, sesungguhnya banyak diharapkan untuk mendukung tercapainya tujuan ideal pendidikan nasional, yaitu pembangunan kesadaran keberagaman menuju terwujudnya kesatuan yang dilandasi oleh nilai-nilai Pancasila dan UUD 1945 (Depdiknas, 2006). Hal ini sejalan dengan apa yang dikedepankan oleh NCSS (2007), bahwa tidak ada satupun cabang kurikulum sekolah yang lebih sentral daripada. Sejarah dan pertumbuhan penting dari semenjak abad lampau merupakan sebuah catatan yang sangat membanggakan, serta memberikan suatu keyakinan bahwa hingga kini tetap sangat dibutuhkan bagi anak. Stanley (2005:7) di dalam pengantar buletin NCSS nomor 175 berjudul Review of Research in Social Studies Education 1983-2005, juga berpandangan bahwa sungguhpun semua mata pelajaran di sekolah bernilai atau berharga bagi anak, akan tetapi tidak ada yang lebih mendasar dan lebih penting dari pada pembelajaran .

Telah banyak inovasi yang dilakukan oleh pemerintah dalam bidang pendidikan, namun sampai saat ini kualitas proses dan produk pendidikan masih Tidak Bagus (Sukadi, 2007). Tidak jarang inovasi kebijakan yang dilakukan, justru mendatangkan masalah baru yang lebih kompleks. Kondisi ini tentu memerlukan berbagai upaya terstruktur dari semua komponen masyarakat, sehingga upaya pencapaian pendidikan yang ideal (bermutu) dapat segera terwujud. Mutu pendidikan banyak dipengaruhi oleh dinamika masyarakat (Hoge, 2003: Lux, 2004), sehingga dalam pengembangan dan pelaksanaannya juga harus mempertimbangkan nilai-nilai lokal masyarakat setempat.

$\mathrm{Di}$ satu pihak, revolusi komunikasi sebagai salah satu dampak dari globalisasi telah menghadirkan seperangkat permasalahan dan sekaligus tantangan bagi dunia pendidikan, khususnya pada jenjang sekolah dasar. Untuk dapat menjadikan siswa sebagai manusia yang berkompetensi global namun tetap berwawasan budaya kebangsaan, sehingga diperlukan seperangkat upaya strategis untuk mewujudkannya (Abijhani, 2006: Farisi, 2006). Menurut Hines (2007) dan Rubba (2006), seiring dengan tuntutan globalisasi, pembelajaran di sekolah dasar sebagai salah satu media pembangunan warga negara, harus mampu membekali dan melatihkan seperangkat kompetensi dan nilai personal kepada peserta didik. Hal ini mutlak untuk dilakukan, karena tujuan pendidikan nasional dengan tegas menyatakan bahwa lembaga 
pendidikan harus mampu menghasilkan manusia-manusia yang berkompetensi global namun tetap berpijak pada keluhuran nilai-nilai budaya bangsanya (UU Nomor 20 Tahun 2003). Untuk kepentingan tersebut, pembelajaran dan segala perangkat yang mendukung harus diarahkan pada upaya menjadikan peserta didik berkompetensi, terampil, dan mampu mengkomunikasikan kompetensi dan keterampilan dirinya secara benar dan sesuai dengan konteks sosial budaya yang dihadapinya (Hasan: 2008).

Pemberlakuan kurikulum 2006 (Kurikulum Tingkat Satuan Pendidikan), telah menghadirkan beribu warna baru bagi guru dalam kegiatan instruksionalnya. Prinsip diversity in unity yang diusung oleh kurikulum 2006, telah menjadikan guru sebagai inovator, develover, and practitioner bagi tugas dan profesinya (Abell and Lewis, 2005: Lasmawan, 2008). Sejalan dengan tuntutan inovasi tersebut, selayaknya pembelajaran pada jenjang sekolah dasar harus dikemas sedemikian rupa oleh guru, agar mampu mendidik dan melatih peserta didik secara dini menjadi warga negara yang berkualitas dan eksis dalam tataran kehidupan global. Untuk kepentingan tersebut, maka pembekalan dan pelatihan nilainilai sosial dan budaya masyarakat kepada peserta didik menjadi keharusan dalam pembelajaran di sekolah dasar.

$$
\text { Pembekalan dan pelatihan }
$$

ketertanggapan sosial (social awareness) kepada siswa dalam melakoni kehidupannya di masyarakat merupakan nilai esensial dalam pembelajaran di sekolah dasar (NCSS, 2008: Jackson, 2005). Siswa sejak dini harus dibekali dan dibiasakan untuk tahu, paham, dan terampil dalam memahami dan melakoni kehidupan yang sesuai dengan nilai-nilai sosial dan karakteristik budaya masyarakatnya (McSavick, 2008). Hal ini sesuai dengan semangat kurikulum 2006 yang menekankan pada penghargaan dan akomodasi potensi lokal dengan standar nasional dan global.

Bertalian dengan preposisi di atas, pembelajaran di sekolah dasar logikanya harus mampu mengakomodasi keberagaman nilai-nilai sosial dan budaya masyarakat setempat, namun tetap dalam patron standar nasional, sehingga mutu pendidikan di sekolah dasar tetap mengacu pada standar pendidikan nasional (BSNP, 2006). Artinya, model pengorganisasian materi, pengembangan materi, dan penerapan materi dalam konteks kelas boleh berbeda dan disesuaikan dengan potensi sekolah dan/atau masyarakat setempat, namun harus tetap pada standar yang sama (nasional). Di sisi lain, dalam pelaksanaan penilaian terhadap keseluruhan kegiatan instruksional, guru juga harus mampu menyesuaikannya dengan karakteristik sosial dan budaya setempat, sehingga siswa tidak mengalami shockh of culture dalam belajarnya, sehingga penilaian tidak mampu menilai keseluruhan potensi siswa.

Secara umum tujuan penelitian ini adalah mengembangkan model pengorganisasian materi dan perangkat penilaian pembelajaran mata kuliah wawasan pendidikan dasar, pendidikan , telaah kurikulum, dan perspektif global yang berbasis sosial budaya secara integratif dan holistik yang mencakup domain kognisi, afeksi, nilai, dan 
psikomotor. Secara lebih rinci, masalah penelitian ini dapat diformulasikan sebagai berikut.

Pertama, mengembangkan model pengorganisasian materi dan perangkat penilaian pembelajaran mata kuliah wawasan pendidikan dasar, pendidikan, telaah kurikulum, dan perspektif global yang berbasis sosial budaya secara integratif dan holistik yang mencakup domain kognisi, afeksi, nilai, dan psikomotor.

Kedua, model akomodasi domain sosial dan budaya dalam pengorganisasian materi dan perangkat penilaian pembelajaran mata kuliah wawasan pendidikan dasar, pendidikan, telaah kurikulum, dan perspektif global yang berbasis sosial - budaya secara integratif dan holistik yang mencakup domain kognisi, afeksi, nilai, dan psikomotor.

Ketiga, mengembangkan perangkat penilaian pembelajaran mata kuliah wawasan pendidikan dasar, pendidikan, telaah kurikulum, dan perspektif global yang berbasis sosial budaya secara integratif dan holistik yang mencakup domain kognisi, afeksi, nilai, dan psikomotor.

Keempat, memformulasikan

model akhir (fixed model) pengorganisasian dan perangkat mata kuliah wawasan pendidikan dasar, pendidikan, telaah kurikulum, dan perspektif global yang berbasis sosial budaya secara integratif dan holistik yang mencakup domain kognisi, afeksi, nilai, dan psikomotor

\section{METODE}

desain Penelitian ini menggunakan (research and development). Untuk mengembangkan

model

pengorganisasian materi, model pembelajaran, buku ajar, dan perangkat penilaian SD berbasis sosial budaya. Penelitian ini akan dilaksanakan secara bertahap selama 3 (tiga) tahun.

Fokus penelitian pada tahun I adalah analisis kebutuhan (need assesment) melalui studi empirik bertalian dengan kurikulum SD tahun 2006, silabus pembelajaran SD, rencana pembelajaran, model pengorganisasian materi, model pembelajaran, kesiapan sekolah dan guru mengembangkan model pengorganisasian materi, model pembelajaran, buku ajar, dan perangkat penilaian SD berbasis sosial budaya, ketersedian sarana dan prasanan pendukung pengembangan model, dan lingkungan serta sumber belajar yang digunakan oleh guru dalam membelajarkan. Hasil penelitian (temuan) pada tahun I (pertama) akan dijadikan sebagai landasan untuk melakukan pengembangan model pengorganisasian materi, model pembelajaran, buku ajar, dan perangkat penilaian SD berbasis sosial budaya.

Berangkat dari fokus penelitian pada tahun I, maka populasi penelitian adalah semua guru SD yang ada di Provinsi Bali. Penentuan sampel penelitian dilakukan secara random sampling. Untuk tahun II, penelitian difokuskan pada pengembangan model pengorganisasian materi, model pembelajaran, buku ajar, dan perangkat penilaian SD berbasis sosial-budaya dan uji coba skala terbatas. Untuk tahun III (ketiga) penelitian difokuskan pada penyempurnaan, pengujian validitas dan reliabilitas model, serta uji coba secara lebih luas pada skala provinsi terhadap 
model pengorganisasian materi, model pembelajaran, buku ajar, dan perangkat penilaian SD berbasis sosial-budaya, yang telah dikembangkan dan diujicobakan secara terbatas pada tahun II.

Keseluruhan data penelitian ini berupa data kualitatif dan data kuantitatif. Bertalian dengan hal itu, maka pengolahan datanya menggunakan analisis non-statistik dan analisis statistik. Analisis non-statistik digunakan untuk memberi makna terhadap deskripsi data yang berkaitan dengan isi, logika inferensi, dan dinamika proses keseluruhan tahapan penelitian. Analisis statistik deskriptif digunakan untuk mendeskripsikan data kuantitatif. Hasil studi empirik pelaksanaan pembelajaran - SD berbasis sosial-budaya yang meliputi pengorganisasian materi, model pembelajaran, penerapan buku ajar, proses pembelajaran, perangkat penilaian, proses penilaian, kesiapan dan pengalaman in-service training guru akan dianalisi secara deskriptif.

Data yang bertalian dengan hasil uji coba model pengorganisasian materi, model pembelajaran, penerapan buku ajar, dan perangkat penilaian unjuk kerja dan hasil belajar siswa, baik yang uji cobanya dilakukan secara terbatas maupun secara luas (skala provinsi) akan dianalisis melalui uji content validity dan interrater validity.

\section{HASIL DAN PEMBAHASAN}

Berdasarkan hasil penelitian
yang telah dilakukan, dimens kesesuaian dan kedalaman materi konten E-Learning mata kuliah wawasan pendidikan dasar didapatkan skor ratarata sebesar 17,24 berada pada kategori bagus, mata kuliah telaah kurikulum didapatkan skor rata-rata sebesar 17,41 berada pada katagori bagus, mata kuliah pendidikan IPS didapatkan skor rata-rata sebesar 17,35 berada pada katagori bagus, matakuliah perspektif global dan problematika pendidikan dasar didapatkan skor rata-rata sebesar 17,24 berada pada katagori bagus.

Indikator "materi wawasan pendidikan dasar, telaah kurikulum, pendidikan IPS, dan persfektif global dan problematika pendidikan dasar sesuai dengan level S2", dari 109 orang yang diteliti, 80 orang menyatakan "sangat sesuai" dan 29 orang menyatakan "sesuai". Berdasarkan hasil tersebut, dapat disimpulkan bahwa materi yang terdapat pada E-Learning sudah sangat sesuai dengan materi yang harus diberikan pada level S2. Indikator "cakupan (kedalaman dan keluasan) materi", dari 109 orang yang diteliti, 82 orang menyatakan "sangat bagus", 27 orang menyatakan "bagus", Berdasarkan hasil tersebut dapat disimpulkan bahwa cakupan (kedalaman dan keluasan) materi pada E-Learning sudah sangat bagus. Indikator "kebaharuan (up to date) materi", dari 109 orang yang diteliti, 70 orang menyatakan "sangat up to date", 39 orang menyatakan "up to date". Berdasarkan hasil tersebut dapat disimpulkan bahwa kebaharuan (up to date) materi pada E-Learning sudah sangat up to date.

Indikator "kesesuaian referensi yang digunakan", dari 109 orang yang diteliti, 79 orang menyatakan "sangat sesuai", 30 orang menyatakan "sesuai". Berdasarkan hasil tersebut dapat disimpulkan bahwa kesesuaian referensi 
yang digunakan pada E-Learning sudah sangat sesuai dengan referensi yang digunakan.

Secara kualitatif, dalam hal kesesuaian dan kedalaman materi konten E-learning, untuk sajian (sistimatika) buku ajar, keruntunan materi setiap bab, keluasan materi pada setiap bab, kedalaman materi setiap bab, keterbacaan buku ajar, komprehensifitas isi materi, kecocokan materi dengan silabus, kecocokan materi dengan tujuan perkuliahan, kecocokan materi dengan tagihan mata kuliah, sistimatika uraian materi per bab, tata bahasa/penggunaan prinsip-prinsip karya ilmiah, ketercakupan materi sajian setiap bab, kekinian dan kekuatan teori dasar yang digunakan, kecocokan materi dengan referensi yang digunakan, penggunaan istilah atau kosa kata dalam setiap bab dikatakan sangat bagus karena telah memenuhi deskriptor yang diharapkan.

Dimensi

pengorganisasian

materi konten E-Learning mata kuliah wawasan pendidikan dasar didapatkan skor rata-rata sebesar 17,33 berada pada kategori sangat bagus, mata kuliah telaah kurikulum didapatkan skor ratarata sebesar 17,41 berada pada katagori sangat bagus, mata kuliah pendidikan IPS didapatkan skor ratarata sebesar 17,36 berada pada katagori sangat bagus, matakuliah perspektif global dan problematika pendidikan dasar didapatkan skor ratarata sebesar 17,33 berada pada katagori sangat bagus.

Indikator "sistematika materi", dari 109 orang yang diteliti, 79 orang menyatakan "sangat bagus" dan 30 orang menyatakan "baik". Berdasarkan hasil tersebut, dapat disimpulkan bahwa sistematika materi E-Learning sudah sangat bagus.

Indikator "koherensi (saling menunjang) materi antar bagian", dari 109 orang yang diteliti, 81 orang menyatakan "sangat koherensi", 28 orang menyatakan "koherensi". Berdasarkan hasil tersebut, dapat disimpulkan bahwa koherensi (saling menunjang) materi antar bagian pada $E$ Learning sudah sangat koherensi. Indikator "logisasi uraian (induktif-deduktif-argumentatif) yang ditampilkan dari 109 orang yang diteliti, 69 orang menyatakan "sangat bagus", 40 orang menyatakan "bagus" Berdasarkan hasil tersebut, dapat disimpulkan bahwa logisasi uraian (induktif-deduktif-argumentatif)

tampilkan secara baik pada E-Learning sudah sangat bagus.

Secara kualitatif, dalam hal pengorganisasian materi konten $E$ learning, sudah dianggap sangat baik meskipun masih ada beberapa komentar teknis yakni tentang penulisan beberapa paragraf agar dibuat lebih teratur susunannya.

Dimensi kepraktisan konten $E$ Learning mata kuliah wawasan pendidikan dasar didapatkan skor ratarata sebesar 21,61 berada pada kategori bagus, mata kuliah telaah kurikulum didapatkan skor rata-rata sebesar 21,81 berada pada katagori sangat bagus, mata kuliah pendidikan IPS didapatkan skor rata-rata sebesar 21,70 berada pada katagori sangat bagus, matakuliah perspektif global dan problematika pendidikan dasar didapatkan skor rata-rata sebesar 21,61 berada pada katagori bagus.

Indikator "kontekstual (uraian terkait dengan hal yang praktis)", dari 
109 orang yang diteliti, 85 orang menyatakan "sangat kontekstual" dan 24 orang menyatakan "kontekstual". Berdasarkan hasil tersebut, dapat disimpulkan bahwa kontekstual (uraian terkait dengan hal yang praktis) pada $E$ Learning sudah sangat kontekstual.

Indikator "kemudahan untuk dipahami”, dari 109 orang yang diteliti, 77 orang menyatakan "sangat mudah untuk dipahami” dan 32 orang menyatakan "mudah untuk dipahami". Berdasarkan hasil tersebut, dapat disimpulkan bahwa materi yang ada pada E-Learning sudah mudah untuk dipahami.

Indikator "terkait dengan bidang kajian/tugas-tugas dalam penyelesaian studi", dari 109 orang yang diteliti, 87 orang menyatakan "sangat terkait" dan 22 orang menyatakan "terkait". Berdasarkan hasil tersebut, dapat disimpulkan bahwa materi yang ada pada E-Learning sudah sangat terkait dengan bidang kajian/tugas-tugas dalam penyelesaian studi.

Secara kualitatif, dalam hal kepraktisan konten E-learning, sudah dianggap sangat bagus dan sangat berguna sebagai referensi dalam menyelesaikan tugas akhir perkuliahan.

Penggunaan bahasa konten $E$ Learning mata kuliah wawasan pendidikan dasar didapatkan skor ratarata sebesar 8,61 berada pada bagus, mata kuliah telaah kurikulum didapatkan skor rata-rata sebesar 8,68 berada pada katagori bagus, mata kuliah pendidikan IPS didapatkan skor rata-rata sebesar 8,67 berada pada katagori bagus, matakuliah perspektif global dan problematika pendidikan dasar didapatkan skor rata-rata sebesar 8,61 berada pada katagori bagus.
Indikator "kelugasan bahasa", dari 109 orang yang diteliti, 100 orang menyatakan "sangat lugas" dan 9 orang menyatakan "lugas". Berdasarkan hasil tersebut, dapat disimpulkan bahwa bahasa yang digunakan pada $E$ Learning sudah sangat lugas.

Indikator "level bahasa yang digunakan", dari 109 orang yang diteliti, 99 orang menyatakan "sangat sesuai" dan 10 orang menyatakan "sesuai". Berdasarkan hasil tersebut, dapat disimpulkan bahwa level bahasa yang digunakan pada E-Learning sudah sangat sesuai.

Secara kualitatif, dalam hal penggunaan bahasa konten E-learning, sudah dianggap sangat lugas dan telah sesuai dengan bahasa akademik meskipun pada sebagian kecil bagian dinyatakan perlu perbaikan bahasa agar sesuai dengan ejaan yang disempurnakan. Pengembangan perangkat pembelajaran mata kuliah wawasan pendidikan dasar dan profesi pendidikan, mata kuliah globalisasi dan problematika pendidikan dasar, mata kuliah pendidikan IPS, dan mata kuliah telaah kurikulum pendidikan dasar bagi penguatan kandungan keilmuan serta kompetensi lulusan program studi magister pendidikan dasar program pascasarjana Undiksha, telah dilakukan dengan tetap bersandar pada visi dan misi serta standar kompetensi lulusan, yang telah ditetapkan oleh Program Pascasarjana Undiksha, dengan tetap mengacu pada akomodasi dan elaborani nilai-nilai sosial dan budaya yang memiliki pertalian dengan kekinian masyarakat dan dinamika kehidupan masyarakat. Disisi lain, pengembangan perangkat pembelajaran untuk ke-4 mata kuliah tersebut dilakukan dengan 
mengacu pada nilai-nilai praktis dan kegunaan dari materi ajar yang dikembangkan bagi kepentingan belajar mahasiswa. Pengembangan materi ajar dalam konstruk perangkat pembelajaran pada 4 mata kuliah tersebut tetap dilakukan dengan mempertimbangkan keluasan dan kedalaman materi serta perimbangan domain kognisi, afeksi, dan psikomotor, sehingga memudahkan bagi mahasiswa untuk memahami materi serta menerapkannya dalam dinamika profesi dan administrasi pendidikan, khususnya pada jenjang sekolah dasar.

Profil akhir atau bentuk akhir dari perangkat pembelajaran mata kuliah wawasan pendidikan dasar dan profesi pendidikan, mata kuliah globalisasi dan problematika pendidikan dasar, mata kuliah pendidikan IPS, dan mata kuliah telaah kurikulum pendidikan dasar berbasis nilai-nilai sosial dan budaya bagi mahasiswa program studi magister pendidikan dasar di lingkungan program pascasarjana Undiksha, terdiri dari: (1) identitas mata kuliah, (2) standar kompetensi, (3) kompetensi dasar, (4) uraian materi, (5) latihan dan pendalaman, dan (6) sumber bacaan atau referensi. Untuk memahami materi yang tersaji dalam perangkat pembelajaran ini harus dimulai dengan membaca secara cermat dan seksama standar kompetensi dan kompetensi dasar serta uraian materi, kemudian mengerjakan soal-soal latihan yang telah melekat pada satuan materi setiap pokok materi atau bab pada masingmasing perangkat pembelajaran.

\section{PENUTUP}

Berdasarkan temuan dan hasil pengembangan penelitian sebagaimana yang telah dideskripsikan di atas, maka dengan bersandar pada pemikiranpemikiran dasar yang ditemukan dan diejawantahkan dalam perangkat pembelajaran sebagai fokus dari penelitian ini, dapat diformulasikan kesimpulan sebagai berikut:

Pertama, pengembangan perangkat pembelajaran mata kuliah wawasan pendidikan dasar dan profesi pendidikan, mata kuliah globalisasi dan problematika pendidikan dasar, mata kuliah pendidikan IPS, dan mata kuliah telaah kurikulum pendidikan dasar bagi penguatan kandungan keilmuan serta kompetensi lulusan program studi magister pendidikan dasar program pascasarjana Undiksha, telah dilakukan dengan tetap bersandar pada visi dan misi serta standar kompetensi lulusan, yang telah ditetapkan oleh Program Pascasarjana Undiksha, dengan tetap mengacu pada akomodasi dan elaborani nilai-nilai sosial dan budaya yang memiliki pertalian dengan kekinian masyarakat dan dinamika kehidupan masyarakat. Disisi lain, pengembangan perangkat pembelajaran untuk ke-4 mata kuliah tersebut dilakukan dengan mengacu pada nilai-nilai praktis dan kegunaan dari materi ajar yang dikembangkan bagi kepentingan belajar mahasiswa. Pengembangan materi ajar dalam konstruk perangkat pembelajaran pada 4 mata kuliah tersebut tetap dilakukan dengan mempertimbangkan keluasan dan kedalaman materi serta perimbangan domain kognisi, afeksi, dan psikomotor, sehingga memudahkan bagi mahasiswa untuk memahami materi serta menerapkannya dalam dinamika profesi dan administrasi pendidikan, khususnya pada jenjang sekolah dasar. 
Kedua, profil akhir atau bentuk akhir dari perangkat pembelajaran mata kuliah wawasan pendidikan dasar dan profesi pendidikan, mata kuliah globalisasi dan problematika pendidikan dasar, mata kuliah pendidikan IPS, dan mata kuliah telaah kurikulum pendidikan dasar berbasis nilai-nilai sosial dan budaya bagi mahasiswa program studi magister pendidikan dasar di lingkungan program pascasarjana Undiksha, terdiri dari: (1) identitas mata kuliah, (2) standar kompetensi, (3) kompetensi dasar, (4) uraian materi, (5) latihan dan pendalaman, dan (6) sumber bacaan atau referensi. Untuk memahami materi yang tersaji dalam perangkat pembelajaran ini harus dimulai dengan membaca secara cermat dan seksama standar kompetensi dan kompetensi dasar serta uraian materi, kemudian mengerjakan soal-soal latihan yang telah melekat pada satuan materi setiap pokok materi atau bab pada masingmasing perangkat pembelajaran.

Bertolak dari kesimpulan penelitian di atas, dapat diajukan saransaran aplikatif (rekomendasi) sebagai berikut.

Pertama, komunitas pakar dan pengembang Pendidikan Dasar yang bergabung di lingkungan perguruan tinggi, lembaga-lembaga keilmuan, maupun forum-forum komunikasi pakar perlu lebih memantapkan rekonstruksi kompetensi dasar Pendidikan dasar, melalui kajian kritis-reflektif terhadap filsafat konstruktivisme dengan berfokus pada: (1) ontologi siswa sebagai subyek pendidikan yang aktif dalam proses pembentukan makna, dan (2) hakikat pendidikan dasar sebagai wahana pembentuk jatidiri siswa sebagai makhluk pribadi, sosial, dan intelektual.
Kedua, Komunitas pakar dan pengembang pendidikan dasar perlu menjabarkan lebih jauh kompetensikompetensi dasar mata pelajaran Sekolah Dasar yang dirumuskan di dalam penelitian ini, ke dalam kompetensi-kompetensi matriks kurikuler, melalui kajian, pemetaan, dan pengembangan lebih jauh terhadap rumusan kompetensikompetensi dari setiap bidang kajian kurikuler yang mampu mendukung ketercapaian kompetensi-kompetensi dasar secara utuh, dengan memperhatikan keragaman konteks implementasi dan pengembangannya. Hal ini penting untuk mendapatkan rumusan-rumusan kompetensi-kompetensi bidang kajian kurikuler mata pelajaran yang dibelajarkan di Sekolah Dasar yang lebih "substantif', sehingga kemudian bisa dirumuskan kompetensikompetensi personal dan akademis Sekolah Dasar yang "formal".

Ketiga, para praktisi Sekolah Dasar perlu mewujudkan secara utuh kompetensi-kompetensi dasar yang dirumuskan di dalam penelitian ini di tingkat praksis, melalui pemahaman secara utuh terhadap kaitan-kaitan fungsional antara kompetensi bidang kajian kurikuler, kompetensi-kompetensi dasar, dan karakter siswa sebagai makhluk personal, sosial, dan intelektual, dari mana kompetensi tersebut diturunkan. Hal ini penting agar pencapaiannya tidak bersifat partikularistik, mekanistik, dan/atau semata-mata karena tuntutan kurikuler.

Keempat, para pakar, pengembang, dan praktisi Sekolah Dasar seyogianya lebih memahami dan menyikapi integralitas organisasi dan struktur muatan kurikulum Sekolah 
Dasar bukan dilihat dari penggunaan konsep dan keterampilan disiplin ilmu secara terintegrasi, melainkan lebih pada integralitas aspek-aspek atau dimensidimensi kajian kurikulernya. Hal ini dipandang mendasar guna mendukung sifat keterpaduan Pendidikan SD, dan agar secara programatik Sekolah Dasar benarbenar menjadi wahana konstruktivistik yang tidak boleh lepas dari realitas dan persoalan kehidupan masyarakat, yang hakikatnya "berdimensi jamak".

Kelima, para pakar dan pengembang kurikulum Sekolah Dasar seyogianya mengembangkan organisasi dan struktur isi kurikulum didasarkan pada prinsip "a student's psychological, sociocultural, and intellectual horizons reconstructions characterbased", bukan berdasarkan pada "structure of discipline". Hal ini penting agar organisasi dan struktur materi Sekolah Dasar lebih kontekstual, relevan, dan bermakna bagi siswa, dan tidak merusak "indigenous structure" yang telah terbentuk dan berkembang pada diri siswa.

\section{DAFTAR PUSTAKA}

Buchori, M. (2001a). Pendidikan Antisipatoris. Yogyakarta: Kanisius.

Dantes, N. (2008). Pengembangan model dan materi pendidikan multikultur dalam siswa kelas awal dan PKn SMP (laporan penelitian). Singaraja: Lembaga Penelitian Undiksha.

Depdiknas. (2006). Kurikulum Tingkat Satuan Pendidikan: - SD. Jakarta: Depdiknas.
Hasan, S. H. (2006). "Tujuan Kurikulum IImu Pengetahuan Sosial". (Makalah). Bandung: UPI Bandung.

Hoge, J. D. (2003). Effective Elementary Social Studies. California: Wadsworth Publishing Company.

Jackson, Philip W. (2005). Handbook of Research on Curiculum. New York: McMillan Publishing Company.

Kertih, W. (2005). Analisis Kurikulum dan PPKn Sekolah Dasar. (Laporan Penelitian). Singaraja: Singaraja: Lembaga Penelitian IKIP Negeri Singaraja.

Lasmawan, W. (2006). Pengembangan model pendidikan berdemokrasi dalam pembelajaran PPKn di Sekolah Dasar. (Laporan Penelitian). Singaraja: Lembaga Penelitian IKIP Negeri Singaraja.

Lasmawan, W. (2007). Pengembangan Model Belajar Jurisprudensi Sosial dalam Pembelajaran di Sekolah Dasar. (Laporan Penelitian). Singaraja: Lembaga Penelitian Undiksha.

Lasmawan, Wayan (2008). Pengembangan model buku ajar berwawasan social-budaya dalam pembelajaran IPS sekolah dasar (Laporan Penelitian). Singaraja: Lembaga Penelitian Undiksha.

Marshall, S. P. \& Dee D. (2000). New Learning Models. Seatle-USA: Prentice Hall.

Michaelis, J. U. (2006). Social Studies for Children in A Democracy. New Jesey, USA: Prentice-Hall, Inc.

NCSS (2008). Conecting Science, Technology and Education of Citizen. Washington D.C.: NCSS. 
NCSS. (2007). Science-TechnologySociety: Social Studies Education for the 2000s. Washington DC: NCSS.

Rahardjo, 2004. Membangun Pendidikan Nasional Menuju Persaingan Global dalam Bidang Ilmu Pengetahuan dan Teknologi. (Makalah). Disampaikan pada Seminar IPTEK di Kampus UNUD Bali.

Rubba, A. P. (2006). "Issue Investigation and Action Skills: Neccesary Components of Precolleges STS Education". Bulletin of Science, Technology \& Society. Vol. 6, Number 2 \& 3.

Skeel, D. J. (2005). Elementary Social Studies: Challenges for Tomorow's World (3rd edition). Orlando, Florida: Holt, Rinehart and Winston, Inc.
Sumantri, E. 2004. Peningkatan Mutu Pendidikan Sekolah Dasar: Model Penerapan Wawasan, Karakteristik Teori dan Metodologi. (makalah). Disajikan pada Pekan Seminar Mutu Pendidikan di LP IKIP Bandung.

Supriyoko, Ki. (2001). Menuai Dampak Pendidikan. dalam Suara Pembaharuan Daily.

Winataputra, U.S. (2001). Reorientasi Pendidikan IImu Pengetahuan Sosial Mengantisipasi Perubahan Sosial di Era Global. Makalah Seminar Nasional dan Kongres Forum Komunikasi $X$ Pimpinan FP/FIS/FKIP Universitas/IKIP se Indonesia serta Kongres HISPI, 22-24 Oktober. 